\title{
DEVELOPING VISUAL ART MEDIA IN LEARNING SPEAKING SKILL FOR STUDENTS OF JUNIOR HIGH SCHOOL
}

\author{
AN ARTICLE \\ Submitted in Partial Fulfillment of the Requirements \\ for the Degree of Sarjana Pendidikan
}

By:

BETTY SIMANJUNTAK

Registration Number: 2133121017

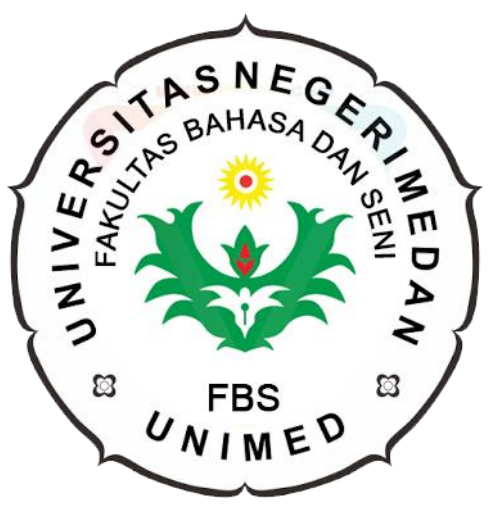

ENGLISH AND LITERATURE DEPARTMENT

FACULTY OF LANGUAGES AND ARTS

STATE UNIVERSITY OF MEDAN

2018 


\title{
DEVELOPING VISUAL ART IN LEARNING SPEAKING SKILL FOR STUDENTS OF JUNIOR HIGH SCHOOL
}

\author{
*Betty Simanjuntak \\ **Prof. Amrin Saragih, M.A., Ph.D. \\ ** Drs. Willem Saragih, Dipl.Appl., M.Pd.
}

\begin{abstract}
Simanjuntak, Betty. Registration Number: 2133121017. Developing Visual Art Media In Learning Speaking Skill For Students Of Junior High School. A Thesis. English Education Study Program, State University of Medan, 2018.

The objective of this study was to develop English learning media based on students' needs. This research was conducted in SMP N 37 Medan for students in grade VII which consists of 30 students. This study followed the steps of research and development proposed by Borg and Gall (1983), which are 1) need analysis; 2) planning (develop preliminary form of product); 3) Collecting data; 4) designing media; 4) media evaluation; 5) revising (designing final product). It was found that $96.66 \%$ students agreed that the existing an interactive learning medium currently used by the students of Junior High School. The more relevant media were developed based on student needs, which can provide opportunities for students to participate in the classroom. The learning media were developed into 4 media based on 4 units of speaking materials. Then the learning media were validated by two experts. The average score of the validation was 90 . It showed that the developed learning media were very good, relevant and feasible.
\end{abstract}

Keywords: $\quad$ English learning media, speaking, visual art media.

\footnotetext{
*Graduate Status

***ecturers Status
} 


\section{ARTIKEL}

\section{DEVELOPING VISUAL ART IN LEARNING SPEAKING SKILL FOR STUDENTS OF JUNIOR HIGH SCHOOL}

Disusun dan Diajukan oleh:

Betty Simanjuntak

NIM. 2133121017

Telah diverifikasi dan dinyatakan memenuhi syarat untuk diunggah pada jurnal online

Medan, September 2018

\section{Menyetujui}

Dosen Pembimbing Skripsi I

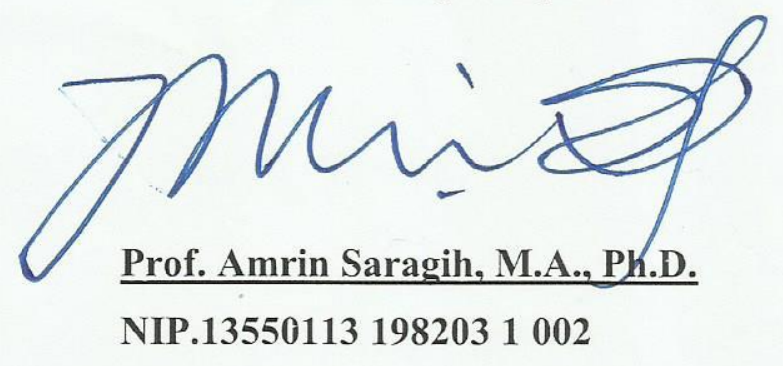

Dosen Pembimbing Skripsi II

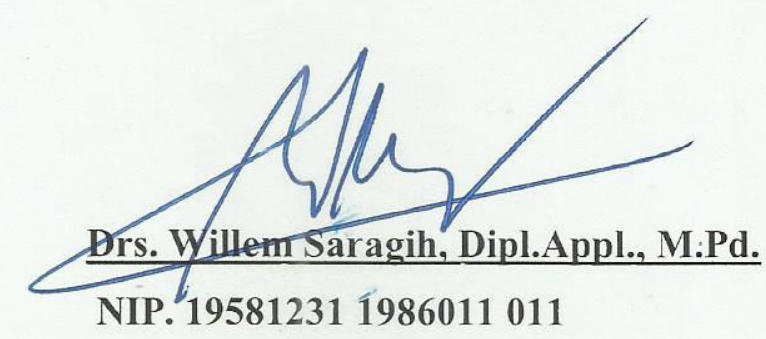

Ka. Program Studi

Pendidikan Bahasa Inggris

Nora Ronita Dewi, S.Pd., S.S., M.Hum.

NIP. 198005222008122003 


\section{INTRODUCTION}

\section{Background of the Study}

In academicals process, school uses a variety of teaching and learning styles. Many learners perhaps most, can and frequently do supply useful representations for them from the information externally available, regardless of medium used (Dabbagh and Kitsanas, 2011). On the other hand, learners will benefit most from the use of a particular medium with certain capabilities.

Media are considered the most efficient facilitators in the education set up. They are not substitutes the teacher. Their use however, calls for an imaginative approach by the teacher who needs to constantly be on the alert for new ideas and techniques to make the lessons presented with different instructional media achieve effective outcomes. Examples of instructional media include traditional means of delivering instruction (chalkboards, textbooks, overhead projectors, and teachers), mass media used for education (newspapers, movies, radio, and television), and the newer "electronic" instructional media (computers, interactive video, and multimedia systems). Many alternative media and mixtures of media may be chosen for any given learning goal and group of students.

Based on the observations of researchers in SMPN 37 Medan, it was found that there are several problems that are faced by the teacher and the students. Firstly, English teacher focus on explaining the material through lecturing method. Secondly, the students feel that speaking English is very difficult without using the learning media.

To solve the problems above the researcher does the study dealing to developing medium that is visual art such as flip book to support the learning process. This is achieved by scrutinizing the available studies dealing with the problems of language learning/teaching in SMPN 37 Medan. It is also an attempt to highlight what can be done to resolve the problems significantly.

Many classroom teachers have perceived the arts as academically unchallenging and a pursuit suitable for entertainment only. This belief permeates Western society's psyche (Efland, 2002). But, when combined with speaking, art can open doors for high levels of analysis and also challenge students to explore 
themselves and their surroundings and thus find opportunities for sophisticated comprehension and communication. By using arts, students can express their thought, ideas and feeling. The ability to decode, interprets, create, question, challenge and evaluate texts that communicate with visual images as well as or rather than words.

\section{REVIEW OF LITERATURE}

Gagne (1984), stating that learning is a process in which an organism changes its behavior as a result of experience. Learn Experience in the life of a person to do something, or take an action premised is, is a result of the learning process. There is a link or an interaction between the learner and the environment during the learning process (Yuniarti, 2004). During learning, experience is gained.

In some cases, the factor of growth and learning will be so inextricably intertwined that either or both words will need to be used. True learning produces changes in behavior of the learner. Every experience produces a change in the mental structure of the learner which in turn affects the conduct of the learner.

Speaking is the productive skill. It could not be separated from listening. When we speak we produce the text and it should be meaningful. In the nature of communication, we can find the speaker, the listener, the message and the feedback. Speaking could not be separated from pronunciation as it encourages learners to learn the English sounds. Johnson and Morrow (1981: 70) stating that speaking which is popular with term 'oral communication', is an activity involving two or more people in which hearers and speakers have to react to what they hear and make their contributions at a speed of a high level.

Learning media includes tools that are physically used to convey the content of instructional materials, which include books, tape recorders, tapes, video cameras, video recorders, films, slides, photographs, graphic images, television and computers. In other words, the media is a component of a learning resource or physical vehicle containing instructional materials in a student 
environment that can stimulate students to learn which can motivate them ( Aritonang Keke, 2008).

The eligibility of the material includes the suitability of the content media with the concept of the material and the learning objectives. Sumiati (2007) states that the use of instructional media including the learning resources, learning tools, the suitability the content or learning materials and the objectives to be achieved.

Barnes, Mosgrove, and Rassouli (1982) list the following media selection criteria: (1) define the objectives (2) availability of the media in the targeted area (3) uncontrollable factors such as government restrictions (4) the behavioral aspects of targeted customer-learner- (5) appropriate media to effectively convey the message (6) considering the cost factors of candidate media.

The history of art is the history of any activity or product made by humans in visual form of aesthetical or communicative purposes, expressing ideas, emotions or, in general, a worldview. Visual art is the area of learning that is based upon only the kind of art that one can see. Although animation often involves advanced technology and high-end computers, an easy way to make an animated movie is to make a flipbook. A flipbook presents a series of pictures in rapid succession so that an audience perceives moving images.

Art has always been an effective tool for teaching and learning among various classes of people. When combined with reading, writing, speaking and listening, art can open doors for high levels of analysis and also challenge students to explore themselves and their surroundings and thus find avenues for sophisticated comprehension and communication. Familiarizing learners with arts is an enjoyable part of authentic learning; the heart and soul that complement mind and body, a powerful integrative force that teaches the whole child social, creative, emotional, intellectual, and physical" (Le Francois, Psychology for Teaching, pg. 499). Moreover, art has a profound ability and also an invaluable tool for teachers at all levels to enhance instruction for English Language Learners. 


\title{
RESEARCH METHODOLOGY AND DATA ANALYSIS
}

\author{
Methodology \\ This research was conducted based on educational Research and \\ Development (R\&D) design proposed by Borg and Gall (1983). Educational \\ Research and Development (R\&D) is a process used to develop and validate \\ educational products. The steps of this process are usually referred to as the $R \& D$ \\ cycle, which consists of studying research findings pertinent to the product to be \\ developed, developing the product based on the finding, field testing it in the \\ setting where it will be used eventually, and revising it to correct the deficiencies \\ found in the field testing stage to indicate that product meets its behaviorally \\ defined objectives.
}

\section{Data Analysis}

The data were collected through observation and questionnaires. First by observing the teaching-learning activity, the researcher got the data from natural situation. Second, the questionnaires were given to media experts, the first was Indra Hartoyo, S.Pd.,M.Hum, an English lecturer of State University of Medan. The second validator was Johny Albert H. Sihombing, S.Pd, an English teacher at SMP N 37 Medan; and students who are in grade VII-B to obtain the data about the quality and eligibility of learning media. The questionnaires were used to determine the assessment and response about leaning media. This research questionnaire used the rating scale. Rating scale was used to rating attitudes, opinions, and perceptions of a person or group of people on the research variables. This scale used four categories: (4) very eligible, (3) eligible, (2) less eligible, and (1) not eligible.

\section{Findings}

The aim of this study was to design the learning media to learn speaking skill that appropriate for the seventh grade students at SMP N 37 Medan. The researcher did the steps of R \& D cycle proposed by Borg and Gall to get the students need by observing and giving questionnaires for the students. The result 
of the learner needs showed that the students need an interactive learning media. The characteristic of the media that they need is, it can give the students chance to participate in the class. So from those findings, it can give the offer a new learning media using flipbook. It can be involved by the students and around 96, $66 \%$ students interested with it. To design the flipbook, the researcher gave a question to the students and the result showed that 93, $33 \%$ students interested with the illustration in the form of image and $100 \%$ students like to do learning in group discussion.

From those results, the researcher designs the learning media that can stimulate the students to learn speaking skill and to help the teacher to find a good media to teaching learning process. To get the quality of the product, the researcher gave it to the validators to be validated. The validators came from English lecturer State University of Medan that was Indra Hartoyo, S.Pd., M.Hum, and an Englsih teacher from SMP N 37 Medan that was Johny Albert H. Sihombing, S.Pd.

As the result from the first validator evaluation got $90 \%$ for the content aspect and got 88, $57 \%$ for the visual aspect. Beside that from the second validator evaluation got $92 \%$ for the content aspect and got $85,71 \%$ for the visual aspect.

After revising the product, the researcher introduce the learning media to class that was consist of 30 students from grade VII-B. There were some steps when introduced the product to the students. First, the researcher informed the teacher how to use the learning media. Second, the researcher demonstrated to the students how to using all of the learning media. After that, the students practiced to use the media by themselves. Then the researcher distributes field of testing questionnaires to the students. As the result 5 students gave very well to the quality of the product.

Based on theoritical and statistic finding, it is concluded that the visual media which is developed in this study is eligible and suitable to be used for learning speaking English. 


\section{CONCLUSION AND SUGGESTION}

\section{Conclusion}

Based on the result of the analysis, was concluded that 1) visual art media which is developed in this study is suitable to be used for learning speaking, because of the data collected through observation and questionnaires. The flip book medium is used as media to support the process of learning English. This progress can be seen from the student's response show that the flip book media increase students' interest in learning, motivate students to learn, the media made the lesson easy to understand, and the media are also good used to improve students' speaking ability; 2) The visual media which is developed in this study is eligible to be used for learning English, because the result of validation from the experts is for the content of the media the average is about $91 \%$ with category very good and the result of validation from the experts is for the visual of the media the average is about $87.14 \%$ with category very good. The researcher designs the learning media that can stimulate the students to learn speaking skill especially related to greetings, introducing self, telling time, and to state public places topics and to help the teacher to find a good media to teaching learning process.

\section{Suggestions}

The writer points out some suggestions. First, it is suggested that the newly developed media should be used by the English teacher to encourage students of Junior High School to do the speaking activities in teaching and learning process. It is important to build students' confidence first to speak because it will influence the teaching and learning process in the class. The second, due to limited time, this research only develops media for four topics of materials for the students. Therefore, it is expected to other researchers to develop English learning media for other grades which have the problems with the availability of suitable English learning media. 


\section{REFERENCES}

Aritonang, T.K. 2008. Minat dan Motivasi dalam Meningkatkan Hasil Belajar Siswa. Jurnal Pendidikan Penabur - No.10.

Barnes, J., Mosgrove B., Rassouli, J., (1982). An objective and task media selection decision model and advertising cost. Journal of Advertising, 11(4).

Borg, W. R. and Gall, M. D. (1983). Educational Research An Introduction. New York: Longman.

Dabbagh, N., Kitsantas, A. 2011. Personal Learning Environments, social media, and self-regulated learning: A natural formula for connecting formal and informal learning.

Efland, A. D. (2002). Art and cognition: Integrating the visual arts in the curriculum. New York: Teachers College Press, Columbia University.

Gagne dan Berliner. 1984. Teori Belajar Behavioristik dan Penerapannya dalam

Pembelajaran. (Online) http://www.maziatul.com/2009/07/teori-belajarbehavioristik-dan.html.

Johnson, K. and Morrow, K.E. 1981. Communication in The Classroom: Handbooks for Teachers' series. London: Longman.

Lefrancois, G. R. (1997). Psychology for teaching ( $9^{\text {th }}$ ed). Belmont, CA: Wadsworth.

Sumiati, Asra. 2007. Metode Pembelajaran. Bandung: CV Wacana Prima.

Yuniarti, E. 2004. Upaya Peningkatan Kualitas Pembelajaran Bahasa Inggris Secara Komunikatif dengan Teknik Picture Cue Cards. Jurnal Penelitian dan Evaluasi Pendidikan, No.1. 